\title{
Perspective of genetic improvement in the culture of pearl oysters
}

\author{
KATSUHIKO T. WADA \\ National Research Institute of Fisheries Science, Fisheries Research Agency, Fukuura, Kanazowa, \\ Yokohama 2368648 Japan (wada@fra.affrc.go.jp)
}

SUMMARY; This paper reviews the recent genetic studies of pearl oysters with reference to future perspective of pearl culture. Using hatchery technique, selective- and crossbreeding, and chromosome manipulation have been conducted. Traits studied were the size, shape and color of shells and maturation and spawning which are important for improvement in terms of production of pearls. Studies on classic breeding have provided the interesting results. Heritabilities of shell traits are rather high and useful for selective breeding in some traits. Chromosome manipulation has not provided stable results in triploid studies applicable to peart culture with variable performance related to sterility. Primary cell cultures derived from several tissues have been made in pearl oyster. Information on molecular genetics has been scarce until recently. Genetic mechanism of peart formation has been studied by cloning of cDNA related to mineralization of pearl substances and will be important for genomics assisted breeding. It is important to conserve the genetic diversity of the populations of each species of pearl oysters to respond to the various demands of farmers or consumers in future with regards to genetic resources.

\section{KEY WORDS: pearl oyster, selective breeding, cross breeding, molecular genetics}

\section{INTRODUCTION}

Pearl oyster is very important bivalve shellfish which has been used for pearl production and the trial to follow the culture techniques developed in Japan has increased in the world. Sustainable pearl culture depends on the breeding of cultured stocks of animals at the local environment of each species or race of pearl oysters. It became obvious that the goal of the genetics in aquaculture would be a sustainable breeding of particular species for better productivity in a sound sustainable environment of aquaculture. ${ }^{11}$ Interests and studies on genetics for stock improvement or enhancement of commercial pearl oysters have been promoted as in other aquaculture species particularly after hatchery production systems had been developed for seeds of mother of pearl. Studies have been conducted on biotechnology such as research of the chromosome manipulation or research based on biochemical or molecular biology. However quantitative genetics is still important to understand the genetic information of each species for improvement of the stock of pearl oyster. Commercial application of bivalve genetics is a process of development and transfer of genetically improved stocks to industry. ${ }^{11}$

This article overviews the state of the industry and the perspective of genetic studies of pearl oysters.

\section{PRODUCTION OF PEARLS IN THE WORLD AND THE SPECIES}

Shell mollusks produce calcified particles, which are the organism's means of excluding or walling off foreign substances by secreting shell around them. Calcified particles with luster of nacre become pearls and can be commercial products as gems. Pearl had been harvested from the wild stocks of pearl oyster since ancient time. The main techniques of the surgical operation methods for producing spherical pearls are said to have been invented in commercial scale by the Japanese pioneers in Pinctada fucata martensii. Since then, many improvements have been made in Japan for the method for rearing the animals, for the operation of insertion of nucleus and graft, for conditioning the physiological activity, for wintering and for cleaning shell etc. in the beginning of pearl culture. These techniques have been extended to other species, $P$. margaritifera, $P$. maxima in Indo-Pacific regions. One of recent statistics reported that percent of production of the pearl are $44.4 \%, 28.8 \%$ and $26.8 \%$ from $P$. margaritifera, $P$. maxima and $P$. fucata (martensii) respectively in $1999 .^{2)}$

\section{MECHANISM OF PEARL FORMATION AND ITS GENETIC CONTROL}

Seeds of pearl oysters have been collected from the natural spats released from the cultured or wild stocks of parents. It is just recently that they started the hatcheries to produce artificial seeds primarily to supply decreased spat of some local wild stocks. Hatchery production provides motivation to genetic breeding for more efficient or sustainable culture of better or valuable pearl. Many traits of mother of pearl were considered for this purpose but the growth, color and shape of shells had been studied before the demand to study physiological traits related to mass mortality increased. A piece of mantle dissected from mother of pearl (donor) is grafted together with a nucleus in the gonad of another individual (host) The graft tissue grows to be a pearl sac surrounding ? nucleus. A pearl occurs in specific solution secreted 
through the pearl sac epithelium.

Quality of pearl depends on the substances secreted from the pearl sac. Size, stain, color, luster, shape, thickness of nacre and other factors are commercially important to evaluate a pearl. Size mainly depends on that of nucleus and larger host would be required to produce bigger size of pearl particularly with deeper convexity of shell. Color, stain, luster and thickness of nacre of pearls may depend on 1) granular and laminar structure of nacre, 2 ) peptides in the nacre and 3 ) organic substances deposited at the beginning of pearl formation. Most of these traits are controlled by the physiological process of calcification of crystals of nacre secreted from the pearl sac. ${ }^{3.5)}$ Mortality and rejection of nucleus are also very important problem during process of pearl cultivation from young stage of oyster to that of harvest of pearl, but are not so well investigated genetically. Studies on estimating the genetic variation or genotype environment interaction of quantitative traits has progressed slowly due to fluctuating variable natural environments of bivalve habitat and difficulties to control rearing condition and to breed large number of mating. ${ }^{1,6)}$

\section{GENETIC VARIATION OF SHELL TRAITS}

Realized heritabilities 0.2 to 0.3 on the shell width and shell convexity of 3 year-old Japanese pearl oysters were estimated from the response to divergent selection for three generations. ${ }^{7-10}$ ) Effective responses were also observed in the frequencies of yellow coloration of shell nacre showing that the frequency of the more desirable shells without yellow pigments (white) increased by the third generation to $80 \%$ from the base population with $20 \%$ of non-yellow pigments. Transplantation of the mantle tissue which were conducted using these populations revealed that yellow pearls were produced at a higher rate in the group of oysters selected for yellow nacre than in those for nacre without yellow pigments. "Weight of pearl was slightly lighter in the group of pearls produced from this transplantation experiment of the mantle tissue of animals selected for non-yellow nacre. Positive correlation was observed between the weight of pearls and that of the shell of host oysters. These results have implications for the selective breeding of host and donor pearl oysters. ${ }^{12,13)}$

External color of the shell is mainly associated with the pigments contained in the prismatic layer of the shells. The white color are rare in the wild type of individuals most of which are brown purple with dark brown spots or stripes. Breeding experiment suggested that the white coloration is inherited under the control of recessive gene $(s)^{14,15)}$ The frequency of yellow pearl was significantly lower in the group produced by grafting mantle tissue from the inbred white line than those from brown lines. ${ }^{16}$

\section{MOLECULAR GENETIC STUDIES ON PERAL FORMATION}

Recent advances of molecular genetic studies revealed the sequences of cDNA which encode proteins in the organic matrix of the bivalve shell or pearls that relate to formation of nacre. ${ }^{1723)}$ Nacrein which is one of water soluble organic matrix (WSM) proteins in the nacreous layer of pearls of $P$. fucata martensii was purified, and cDNA cloning was carried out. ${ }^{18)}$ It is interesting that nacrein was suggested to function as a matrix protein whose repeated Gly-Xaa- Asn ( Xaa=Asp, Asn or Glu ) domain possibly binds calcium and as carbonic anhydrase that catalyzes the $\mathrm{HCO}_{-3}$ formation thus participating in calcium carbonate crystal formation on the nacreous layer. Other researchers ${ }^{21 \cdot 23}$ ) isolated many cDNAs of the framework proteins from the nacreous and prismatic layers of the pearl oysters, $P$. fucata martensii and $P$. moxima, and suggested that the proteins in the pallial part of mantle construct the nacre and those from the edge of mantle construct the prismatic layer by binding selectively soluble aspirate-rich matrix glycoproteins and carbonic anhydrase.

The new matrix protein N16 isolated from the water insoluble matrix (WISM) of nacre of $P$. fucata fucata induced aragonite crystals when fixed on the substrate resulting in crystalline layers highly similar to the nacreous layer in the in vitro studies. ${ }^{2)}$ It was also reported ${ }^{22.23)}$ that the repeat sequences of N66 and N14 (matrix proteins from WSM and WISM of $P$. mcxima nacre ) were longer than those of homogeneous proteins of $P$. ficata fucata nacre (nacrein and N16 ). They suggested that the longer repeat sequences of $\mathrm{N} 66$ and $\mathrm{N} 14$ might be responsible for its excellent property of calcification of $P$. maxima. ${ }^{23)}$ This would be useful in the genomics assisted breeding strategy of pearl oyster suggesting their roles in crystallization of nacre. From the point of molecular genetics, polymorphic markers should be also detected for marker assisted selective breeding of pearl oysters.

\section{STUDIES ON TISSUE CULTURE}

Development of tissue or cell culture techniques is important for the fundamental or applicable tools of not only genetics but also pathology, immunology and physiology of bivalve molluscs. In vitro studies of pearl formation was reviewed including cell and tissue culture of bivalve molluscs. ${ }^{24}$ Main reason of the difficulties to obtain cell lines of tissues or cells was reported to be suitable media for proliferation of cell and preventing the propagation of other organisms particularly chytrid-like zoospoic fungus. Trials to establish cell line has faced to the contamination and proliferation of cells of this kinds of organisms. The micrographical features are much similar to those of cells of molluscan tissues which proliferated in cell cultures. Growth factor like substances were not reported from the pearl oysters which was demonstrated in the mussels. ${ }^{25}$ 
GENETIC IMPROVEMENT FOR SUSTAINABLE PRODUCTION OF PEARL AND PERSPECTIVE IN PRODUCTION SYSTEMS

\section{Mortality and physiological traits}

In order to improve high mortality, practical studies on cross breeding or hybrid vigor of pearl oyster were made using intra- or intersubspecific hybridization. Hybridizing experiments was conducted by using some different local populations isolated geographically or selection lines to improve shell traits or mortality. ${ }^{11} P$. fucata fucata and its subspecies $P$. fucata martensii were used. Shell convexity or shell width generally showed intermediate value between those of parental inbred lines and the mortality of the two reciprocal crossing lines were better than those of inbred lines. These results may show a heterosis and suggest part of the traits could be inherited and improved by cross breeding. Programs on selection and hybridization trials are on the way with regards to resistance to summer mortality or high temperature in Japan.

\section{Studies on artificial triploid}

Triploid bivalve exhibits three sets of genome and this fact influences to the many traits of the animals. Attempts of detailed evaluation of triploid bivalve have been made in the pearl oyster. ${ }^{26-30)}$ Growth rate has been reported to be improved in triploid pearl oysters at the stage of maturation compared with diploid animals as well as other aquacultured bivalve species. Triploid Japanese pearl oyster became much larger after maturation stage ( ca. 1 year of age) presumably because the energy for maturation was converted to growth. ${ }^{28)}$ Similar results were also reported in China. in) The results of evaluation of trait on maturation in triploid pearl oysters varies depending on species, age, the location (environment) of the farms and the season of harvesting. For examples the degree of the retarding maturation of gonad varies among location. Some triploid pearl oysters produced spermatozoa and oocytes, although the number of gametes in the gonads was substantially reduced compared with the diploid animals in Japan. ${ }^{29)}$ Meanwhile the Chinese species was reported to be sterile without any gonadal development in triploid animals although histological illustrations have not presented. ${ }^{26)}$ It is necessary to determine wether they affect natural or cultured populations when we apply triploid of pearl oyster to the farms particularly where the wild stock is reproduced.

Genetic diversity in the wild population and its conservation

Geographic variation of some traits was reported in the wild population of the Japanese pearl oyster, $P$. fucata martensii." ${ }^{31}$ The populations from Namako lagoon of Kosikijima Island, Kagoshima Prefecture, Kyushu and those from Ryukyu Islands were different from those from the mainland of Japan in the frequencies of types of prismatic layer or pearl layer coloration of shells and allele at four allozyme loci and in shell shape.") Results of some inbreeding and crossing experiments suggested that much of the difference to be inherited. Intraspecific differences of breeding cycle was suggested among the different geographical populations of each species of pearl oysters and these variation has been suggested to be inherited. ${ }^{32}$

Although high genetic variation were found within the single population of $P$. margaritifera, the wild populations separated by several hundred kilometers showed little differences in allozyme variability in French Polynesia. ${ }^{33-35}$ ) Similar results were reported in the Japanese $e^{36)}$ and western Pacific ${ }^{37}$ populations of $P$. margaritifera and in the western Australian $P$. maxima population, ${ }^{38)}$ suggesting relatively high gene flow among populations in open ocean. This seem true in all species of pearl oysters which distributed along ocean current. Recent microsatelite marker analysis suggested some differentiation among stocks in Western Australia. ${ }^{39)}$ It is important to conserve the genetic diversity of these populations of each species of pearl oysters to respond to the various demands of farmers or consumers with regards to biological, physiological, ecological or economical changes in future production systems.

\section{REFERENCES}

1. Wada KT. Genetic improvement of stocks of the peari oyster. In Fingerman M. and Nagabhushanam R (eds) Recent Advances in Marine Biotechnology Vol. 4: Aquaculture, Part A: Seaweeds and Invertebrates. Science Publishers, Inc., 2000, Enfield, NH, U.S.A., pp.75-85.

2. Anonymous. Tahitian pearls constitute $28.8 \%$ of world market. SPC Pearl Oyster Information Bulletin 2000; 14:38.

3. Wada K. Biomineralogical studies on the mechanism of pearl formation. Bull. Natl. Pearl Res. Lab. 1962; 8: 9481059 (In Japanese with English summary) .

4. Wada K. Relationship between metabolism of pearl sac and pearl quality. Bull. Natl. Pearl Res. Lab. 1972; 16: 1949. 2027 (In Japanese with English summary).

5. Wada K. Genetical and physiological control of calcification in pearl cultivation. Bull. de l'Insitut océanographique, Monaco, $n^{\circ}$ spécial 14 1966; 4: 183193.

6. Gervis $\mathrm{MH}$, Sims NA. The biology and culture of pearl oysters (Bivalvia: Pteriidae) . ICLARM Stud. Rev, 21 Oversea Development Administration UK, 1992, 49p.

7. Wada KT. Genetic selecion for shell traits in the Japanese pearl oyster, Pinclada fucata martensii. Aquaculture 1986; 57: 171-176.

8. Wada KT. The Japanese pearl oyster, Pinctada fucata (Gould) (Family Pteriidae). In Menzel W (ed) Esturine and Marine Bivalve Mollusks Culture. CRC Press, Boce Raton, FL. U.S.A., 1991, pp. 245-260.

9. Wada KT. Genetics of pearl oyster in relation to 
aquaculture. JARQ (Japn. Intnatl. Res. Cntr. Agri. Sci. Min. Agri., Forest Fish., Tsukuba, Japan) 1994; 28: 276282 .

10. Wada KT. Aquaculture genetics of bivalve molluses: a review. In Xu H, Colwell RR (eds) Proc. Inertnatl. Symp. Progress Prospect. Mari. Biotechn. (ISPPMB '98) China Ocean Press, Beijing, China, 1999; pp.52-67.

11. Wada KT. Breeding study of the Japanese pearl oyster, Pinctada fucata martensii. Bull. Natl. Res. Inst. Aquaculture 1984; 6: 79-157 (In Japanese with English summary).

12. Wada KT, Komaru A. Estimation of genetic variation in shell traits of the Japanese pearl oyster. Bull. Natl. Res. Inst Aquaculture 1991; 20:19-24.

13. Wada KT, Komaru A. Effect of selection for shell coloration on growth rate and mortality in the Japanese pearl oyster, Pinctada fucata martensii. Aquaculture, 1994; 125:59-65.

14. Wada KT. White coloration of the prismatic layer in inbred Japanese pearl oyster, Pinctada fucata martensii. Bull. Natl. Res. Inst. Aquacuulture 1983; 4: 131-133 (In Japanese with English summary).

15. Wada KT, Komaru A. Inheritance of white coloration of the prismatic layer of shells in the Japanese pearl oyster Pinctada fucata martensii and its importance in the pearl oyster industry. Nippon Suisan Gakkaishi 1990; 56: 1787. 1790 (In Japanese with English summary) .

16. Wada KT, Komaru A. Color and weight of pearls produced by grafting the mantle tissue from a selected popuation for white shell color of the Japanese pearl oyster Pinctada fucata martensii (Dunker) . Aquaculture 1996; 142: 25-32.

17. Belcher AM, Wu XH, Christensen RL, Hansman PK, Stucky GD, Morse DE. Control of crystal phase switching and orientation by soluble molluscs-shell proteins. Nature 1996; 381: 56-58.

18. Miyamoto $\mathrm{H}$, Miyashita $T$, Okushima $T$, Nakano $S$, Morita T, Matsuhiro A. A carbonic anhydrase from the nacreous layer in oyster pearls. Proc. Natl. Acad. Sci., U.SA. 1997; 93: 9657-9660.

19. Bowen $\mathrm{CE}$, Tang $\mathrm{H}$. Conchiolin-protein in aragonite shells of mollusks. Comp. Biochem. Pysiol. 1997; 115A:269-275.

20. Shen X, Belcher AM, Hansman PK, Stucky GD, Morse DE. Molecular cloning and characterization of lustrin $A$ a matrix protein from shell and pearl nacre of Haliotis rufescens. J. Biochem. Pysiol. 1996; 272: 32472-32481.

21. Sudo S, Fujikawa T, Nagakura T, Ohkubo T, Sakaguchi K, Tanaka M, Nakajima K. Structures of molluse shell framework proteins. Nature 1997; 387: 563-564.

22. Samata $T$, Hayashi $N$, Kono $M$, Hasegawa $K$, Horita $C$ and Akera $S$. Anew matrix protein family related to the nacreous layer formation of Pincatada fucata. FEBS Letter 1999; 462: 225-2129.

23. Kono M, Hayashi N, Samata T. Molecular mechanism of the nacreous layer formation in Pinctada maxima. Bioch. Biophys. Res. Comm. 2000; 269: 213-218.

24. Machii A. In vitro studies of pearl formation. Applied Cell Biol, 1998; 15: 1-10 (In Japanese with English summary)

25. Awaji M, Suzuki T. Monolayer formation and DNA synthesis of the outer epithelial cells from pearl oyster mantle in cocultur with amebocyte. In Vitro Cell. Dev. Biol., Animal, 1998; 34: 489-491.

26. Jiang W, Li G, Xu G, Lin Y, Qing N. Growth of the triploid pearl oyster, Pinctada martensii(D.) Aquaculture 1990; 111: 245-253,

27. Jiang WG, Xu G, Lin Y, Li G. Comparison of growth between triploid and diploid of Pinctada martensii (D.) Trop. Oceanogaph. 1991; 10: $1-7$ (in Chinese with English summary ).

28. Komaru A, Wada KT. Gametogenesis of triploid Japanese pearl oyster, Pinctada fucata martensii. In Hoshi and Yamashita(eds) Advances in Invertebrate Reproduction. Elsevier, Amsterdam, 1990, pp.469-474.

29. Komaru A, Wada KT. Gametogenesis and growth of induced triploid Japanese pearl oyster, Pinctada fucata martensii. Suisanzoshoku 1994; 42: 541-546. (In Japanese with English summary).

30. Uchimura $Y$, Abe $S$. Formation of the pearls in triploid Japanese pearl oyster, Pinctada fucata martensii and the pearl produced. Suisanzoshoku 1995; 43: 483-489 (In Japanese with English summary).

31. Wada KT. Inter- and itraspecific electrophoretic variation in three species of the pearl oysters from the Nansei Island of Japan. Bull. Natl. Res. Inst. Aquaculture 1982; 3: 1-10.

32. Wada KT, Komaru A, Ichimura $\mathrm{Y}$, Kurosaki $\mathrm{H}$. Spawning peak occurs during winter in the Japanese subtropical population of the pearl oyster, Pinctada fucata fucata (Gould, 1850). Aquaculture 1995; 133: 207-214.

33. Blanc F. Estimation du polymorphisme enzymatique dans trois populations naturelles de nacre(Pinctada margaritifera) en Polynesie francaise. C. $R$ Acad. Sci. Paris 1983; 297: 199-202.

34. Blane, F. and F. Bonhomme. Polymorphisme genetique des populations de Mollusques d'interet aquicole. In Tiews K (ed) Proc. World Symp. on Selection, Hybridization and Genetic Engineering in Aquaculture, Bordeaux, 27-30 May 1986. vol I, Heeneman, Berlin, 1987, pp. 61-78.

35. Durand $P$, Blanc $F$. Diversite genetique chez un bivalve marin tropical:Pinctada margaritifera (Linne, 1758). Bull. Soc. Zool. Fr. 1989; 113: 293-304.

36. Durand $P$, Wada $K T$, Blanc $F$. Genetic variation in wild and hatchery stock of the back pearl oyster, Pinctada margaritifera, from Japan. Aquaculture 1993; 110: 27-40.

37. Benzie JAH, Ballment E. Genetic differences among black-lipped pearl oyster (Pinctada margaritifera) populations in the Western Pacific. Aquaculture 1994; 127: 145- 156.

38. Johnson MS, Joll LM. Genetic subdivision of the pearl oyster Pinctada maxima (Jameson, 1901) (Mollusca: Pteriidae) . Aust. J. Mar. Freshwater Res. 1993; 44: 519.526.

39. Benzie JAH, Smith $\mathrm{C}$, Wilson $\mathrm{K}$. Genetic variation among Western Australian pearl oyster (Pinctada maxima) populations: A microsatellite survey. Abstract of Symp. Genet. Aquaculture 15-22 July 2000 Townsville, Australia, pp. 13. 